recalled. But my last word must not be an unqualified Ichabod. The engineers of to-day have as much courage and enterprise as their fathers, and they have an infinitely better understanding of the scientific principles on which, as on a smooth highway, the advance of engineering must steadily proceed. Moreover, to recognise evils, and the causes of evils, may be the first step towards their cure. The world has learnt, through a sharp lesson, that the gifts of the engineer are good gifts only if they are wisely used; that the new powers he has evoked have brought new dangers against which mankind must resolutely guard if it is to save its soul alive. The malignity of individuals and the madness of nations now command forces of destruc- tion such as more primitive communities never knew, and were happier not to know ; and apart from clamant and appalling abuses of gifts which ought to be beneficent, we have become aware of a more subtle and perhaps graver social menace. We see the mechanised arts of production overreaching themselves, supplying commodities in a volume which cannot be absorbed, and with a facility that tends to deprive man of his richest blessing to body and spirit-the necessity of toil.

But these thoughts take us too far afield. They point to problems now conspicuously urgent, which, for the salvation of society, the engineer, the economist, and the moralist must jointly set themselves to solve.

\title{
The British Association Centenary.
}

\section{Commemorative Service at Liverpoor Cathedral.}

$\mathrm{T}$ HE Dean and Chapter of Liverpool lose no occasion to make their great Cathedral the scene of public commemoration, and the centenary meeting of the British Association for the Advancement of Science was celebrated there with a ceremony on Sunday, Sept. 20, which will remain vivid in the minds of everyone who assisted in it. It happens that this year's Lord Mayor of Liverpool, Alderman Edwin Thompson, was one of the Association's local secretaries for the meeting in Liverpool in 1923, and is the son of a local secretary of the meeting of 1896 . He was therefore able in a special sense to express the feelings of Liverpool people on this occasion; he entertained the president. and president-elect of the Association at the Town Hall, and conducted them in full state to the Cathedral, where representatives of the University of Liverpool, the medical profession, and other public bodies, in academical robes, made a bright mass of colour in the choir, and the nave was filled to the doors; indeed, the greater part of the service had to be repeated later in the day. The thanksgiving service fell into three parts. The Dean, with the two presidents, and other members of the Association, presented themselves before the Bishop at the junction of choir and nave, and the presidentelect, General the Rt. Hon. J. C. Smuts, addressed him in the following words :

Sir,-Bid a Blessing on this congregation assembled to render thanks for the increase of knowledge by the devoted labours of men and women in many lands, and more especially for the British Association for the Advancement of Science. This body was established a hundred years ago to give more systematic direction to scientific inquiry, to promote intercourse between those who cultivate science in different parts of the British Empire with one another and with philosophers of other countries, to direct the general attention to the objects of science, and to remove disadvantages of a public kind which impede its progress. The Spirit of God has used it to interpret the process of Nature and the doings of man, and by unrestricted interchange of observations, projects, and beliefs, the outlook of the nations on the world in which they live has been transformed. Vain fears and anxieties have been assuaged by clear thinking and wise endeavour. The real dangers and perplexities of our daily lives have been relieved by forethought and mutual help. The amazing structure and intricate processes of the universe have been set forth for reverent and devoted. contemplation by students young and old, of all sorts and conditions. In these several ways human sympathy has been widened in the common task of mutual enlightenment and public service, men's minds have been awakened to the revelation of that which works in all and through all, and their grasp has been strengthened on the principles and the meaning of life.

The Bishop replied to General Smuts in historic words, as follows :

May God, the Fountain of all knowledge, fill you, who have gathered in this house for commemoration, with understanding and joy. May $\mathrm{He}$ keep you steadfast and persevering in your search for truth. And may the blessing of the Lord come upon you abundantly.

O Thou, who in every generation hast moved Thy chosen servants to seek Thy truth: continue we beseech Thee, so to inspire us in this age that, searching the works of Thy hands, we may find Thee in all that Thou hast made, and finally may know Thee perfectly revealed in the Spirit of thy Son, Jesus Christ our Lord.

A lesson was read from Ecclesiasticus xliv., by the president, Prof. F. O. Bower, "Let us now praise famous men, and our fathers that begat us ", and an anthem was then sung :

Lord, who hast made us for Thine own, hear as we sing before Thy throne.

Alleluia, Alleluia.

Accept Thy children's rev'rent praise for all Thy wondrous works and ways.

Waves, rolling in on ev'ry shore, pause at His footfall and adore,

Ye torrents rushing from the hills, bless Him whose hand your fountain fills.

Earth, ever through the power divine, seedtime and harvest shall be Thine.

Sweet flowers that perfume all the air, thank Him that $\mathrm{He}$ hath made you fair.

Burn, lamps of night, with constant flame, shine to the honour of His name.

Thou sun, whom all the lands obey, renew His praise from day to day.

Alleluia, Alleluia.

The commemoration was delivered, in the form of a bidding prayer, by Prof. J. L. Myres, one of the

$$
\text { No. 3231, VoL. 128] }
$$


general secretaries of the British Association, and formerly Gladstone professor of Greek and lecturer in ancient geography in the University of Liverpool. After each prayer the response of the Dean was "Bless ye the Lord", and of the congregation "Praise him and magnify him for ever".

Ye shall remember those who in all times and in all places have devoted their gifts of intellect and imagination to interpret the laws of thought, the place of man in the universe, and the nature of reality;

Such as were Aristotle, Da Vinci, Bacon, Descartes, and Kant.

Ye shall remember all who have explored the properties of numbers, and the mysteries of time and space;

Such as were Pythagoras, Archimedes, Newton, Leibniz, Gauss, and Poincaré.

Ye shall remember all who have determined the courses of the stars, the place among them of sun, moon, and this earth of ours, and have given to all those, whose business is in the great deep, sure guidance to the haven where they would be;

Such as were Ptolemy, Copernicus, Kepler, Tycho Brahe, Halley, Herschel, and Huggins.

Ye shall remember all whose profound vision and infinite patience have revealed the ever-changing uniformities of the great forces of Nature; and made light and sound, heat and cold, lightning, wind, and flood subservient to the purposes of man;

Such as were Galileo, Gilbert, Watt, Faraday, Joule, Clerk Maxwell, Rayleigh, Hertz, and Parsons.

Ye shall remember all who have distinguished the natural elements, verified their properties and affinities, and thereby compounded substances unknown before, serviceable to health and in the arts ;

Such as were Paracelsus, Boyle, Dalton, Priestley, Lavoisier, Davy, Berzelius, and Mendeleeff.

Ye shall remember all to whose vision across the ages the mountains and the seas are but of yesterday; who have laid bare the foundations of the world, and revealed its hidden treasures surely and safely for our uses ;

Such as were Hutton, Nicolaus Steno, William Smith, Lyell, Bouchier de Perthes, and Suess.

Ye shall remember all who, not sparing life or fortune, set forth to find and win new homes for the multitude of our folk, to build the waste places of the earth, so that the desert should rejoice and blossom, and the men who stood far off might see a great light; for all travellers and explorers, and for those who were moved by great thought to send them forth, and to set down and make known their discoveries;

Such as were Marco Polo, Prince Henry the Navigator, Christopher Columbus, Banks, Cook, Humboldt, Franklin, Livingstone, Nansen, and Scott.

$\mathrm{Ye}$ shall remember all who have set in order the lineage of all living things, animals and plants, observed their habits and haunts, their struggles and survivals through the long lapse of time, the wonderful variety, infinite beauty, and subtle adaption of each to its proper life; their coming to birth and passing away: who have distinguished among them the friends and the foes of man, and sought to diversify by human skill the manifold works of creation ;

Such as were Hippocrates, Galen, Linnæus, Cuvier, Lamarck, Darwin, Hooker, Huxley, and Mendel.

Ye shall remember all who have applied the principles of the several sciences to the tillage of the soil, the avoidance of famine and pestilence, the breeding and sustenance of flocks and herds, and the abundant provision of our daily bread;

Such as were Jethro Tull, Daubeny, Liebig, Lawes, and Theiler.
Ye shall remember all who, by their intimate study of the functions of life, have made plain the mysteries of many diseases and abated their ravages; and brought knowledge of our bodily frame to the better study of the mind in sickness and in health;

Such as were Vesalius, Harvey, Hunter, Claude Bernard, Johannes Muller, Pasteur, and Helmholtz.

Ye shall remember all whose contemplation of the divers races of mankind, the manner of their lives, the ordering of their societies, their customs and beliefs, and their manifold dealings each with his neighbour, for the enjoyment of Nature's gifts and the fruits of reason and toil, to the increase of the wealth of nations, have contributed to mutual understanding among the peoples and peace on earth among men of good will;

Such as were Bodin, Locke, Montesquieu, Adam Smith, Quetelet, Galton, and Tylor.

Ye shall remember all by whose precept and example, schools, colleges, and universities have been founded, so that true religion and sound learning may ever flourish and abound; for all teachers of those who learn; for all guides and masters of those who teach ;

Such as were Socrates, Plato, Herbart, and in our own land William of Wykeham, Colet, and Arnold, Thring, Sanderson, and all founders and benefactors of the University of Liverpool.

The Bishop, at the end, taking up the same theme in more general terms, said :

And lastly, let us remember all who in the wise use of their abundance or their power, by their gifts of tongue and pen, by their particular skill, industry, and patience, have contributed to the advancement of learning, the application of science to the common good, or to the spread of the new light of reason among dark places and cruel habitations. Line upon line, precept upon precept, here a little and there a little, the works of each proclaim the Spirit of Him who wrought in them.

Then, after a hymn, the sermon was preached by the Bishop of Birmingham, Dr. E. W. Barnes, on the words, "The things that are not seen are eternal".

Finally, after hymn and anthem, the congregawas dismissed with blessing by the Bishop.

In the evening a more informal gathering, such as is customary in Liverpool Cathedral, was conducted by the Chancellor of the Diocese, and addressed by General Smuts and Sir Oliver Lodge. The Cathedral was full, and an even larger number was turned away.

\section{Sectional Meetings and Discussions.}

The meetings of the British Association have become part of our intellectual life as a nation and as an Empire. The general public awaits with an eager interest the messages of our leaders of thought about the actual trend of civilisation, while research students expect to find in their pondered pronouncements an indication of the landmarks in the unknown reached by science, and inspiring examples and methods for its own studies. The meeting of the British Association this year had, however, a wider interest, owing to the centenary celebrations of its foundation. When one looks back on the work of the Association during these hundred years from its first meeting organised at York by 
Brewster and a band of enthusiastic men of science, one can only recognise the immense services it has rendered to science and the growing importance of its work.

The opening address of General the Right Hon. J. C. Smuts and summaries of the addresses of the presidents of sections have already appeared in Nature of Sept. 26. Taken together, they represent a broad survey of what science has done in recent years and what is to be expected of it in the near future. The problems of the constitution of matter, of the origin of life, of the various aspects of physiology, and of the increase and applications of mechanical power have been restated and broadly illustrated, while the papers read at the sectional meetings have considered special points of particular interest in the various branches of knowledge, from asymptotic partition formulæ to London tunnelling problems, the psychology of facial expression, or the early bronze age site in western Macedonia.

Questions dealing with integral calculus, higher pure geometry, and the application of mathematics to such problems as the relativistic wave equation, viscosity, and molecular physics seem to have been prominent among the mathematicians; while questions referring to the invention and use of powerful optical instruments and to the study of atmospheric conditions have been dealt with in the department of cosmical physics. The outstanding discussion in the department of Section A was one on the evolution of the universe, opened by Sir James Jeans at a crowded assembly in the Central Hall, Westminster. We propose to publish in a later issue the contributions to this discussion. In the Chemistry Section, much interest was shown in the study of the properties of electrolytes in various conditions, and also in the constitution and biological effects of vitamins, as well as in molecular and atomic structures. A fine collection of exhibits of various chemical compounds added to the practical value of this important section.

Geologists were interested to hear of the unknown prehistoric conditions of the London district. But the conflicting views of Sir Arthur Keith, Prof. H. L. Hawkins, Prof. H. F. Osborn, Prof. Swinnerton, Prof. A. E. Trueman, Prof. D. M. S. Watson, and Dr. W. D. Lang on the evidence of palæontology with regard to evolution could scarcely serve as a safe guide to the layman in one of the fundamental questions affecting the human race. Geological problems, however, are closely connected with geography; so that the transition between these two sciences appears to be easy and natural. The retrospect of geography at the British Association, sketched out by Dr. H. R. Mill, was a useful introduction. Yet the trend of the discussions has shown that physical geography rather than descriptive geography has the favour of the man of science. Perhaps we know already too much about what we have on our planet: what we want to know is how all this came about, or, to put it in technical terms, what are the origin and nature of the earth's crust.

As would be expected, zoology was dominated by inquiries on evolution, natural selection, genetics, and Mendelism, applied to the whole range of living organisms; while physiology dealt with the advanced aspects of the subject, especially with reference to human beings. A most interesting discussion in this connexion was that on problems of resuscitation from asphyxia, electrocution, drowning, etc., when the learned diagnoses of Sir Bernard Spilsbury, Prof. Y. Henderson, Prof. J. S. Haldane, Sir Francis Shipway, and other experts were given. Mechanical causes, inhalation of air deprived of oxygen, paralysis of the respiratory centres were considered under their various aspects as the chief causes producing asphyxia, and methods of resuscitation were suggested. Going further into the problems of the human complex, psychologists discussed the diverse questions pertaining to child psychology, analytical and abnormal psychology, and the experimental side of their inquiries. The delicate subject of mental deficiency and the psychology of the senses were also among the items considered. On the other hand, the ancient history of man was presented in a series of technical papers in the section of anthropology, in which primitive races and prehistoric man were studied side by side. Among the archæological theories put forth in this section, Dr. R. E. Mortimer Wheeler's paper on the excavations of Verulamium (St. Albans) was of a special interest.

Botany and agriculture received also full consideration. Plant morphology and plant diseases, especially the questions connected with wood preservation in forestry, were carefully analysed. At the same time the practical value of botany was the subject of a symposium on the training of botanists for economic and industrial positions, in which Sir Arthur Hill, Sir John B. Farmer, Prof. V. H. Blackman, Dr. W. B. Brierley, and Mr. J. Ramsbottom took part. Problems referring to agriculture proper were dealt with in a variety of papers which should prove of immense value to the practical side of farming, cattle breeding, and the allied arts of the countryside. The economic questions relating to agriculture in the British Empire were also discussed generally.

Economic science had naturally an important part to play in the meeting, and the sections devoted to economics and statistics, with the connected subjects of industry and engineering, scored high in the proceedings with some brilliant papers by experts and leaders of industry. A cursory remark may also be made about the section of education, in which the suggested establishment of a central institute for imperial education was thoroughly discussed.

On the whole, the addresses and papers read at the centenary meeting of the British Association show conclusively that if the scientific worker knows more and more about Nature, he is less and less inclined to present any clear-cut or definitive solutions to the major problems he sets forth to answer. A quarter of a century ago, the positivistic and materialistic conception of science allowed him a greater pride, almost a sense of infallibility, about his conclusions. Now, however,

No. 3231, VoL. 128] 
the very magnitude of his knowledge compels him to greater modesty. Perhaps that is the proper attitude he should adopt; if one admits that the final light that man seeks in this world should come from other sources which, though different from those of science, tend, however, to mould the human mind and its aspirations into a nobler and finer unity.

The freedom of the City of York was conferred on General Smuts when an invited party visited the city on Sept. 26.

At a reception given by the University of London on Sept. 28, the vice-chancellor delivered an address of welcome to the delegates to the centenary meeting, and then, by desire of the Senate, conferred the honorary degree of doctor of science, Honoris Causa, on the following :

General the Rt. Hon. Jan Christiaan Smuts, C.H., F.R.S. ;

Prof. Sir Frederick Gowland Hopkins, P.R.S.;

Sir Joseph John Thomson, O.M., F.R.S. ;

Sir Charles Scott Sherrington, O.M., G.B.E., F.R.S.;

The Rt. Hon. Lord Rutherford of Nelson, O.M., F.R.S.

\section{OFFICERS AND COUNCIL.}

Sir Alfred Ewing, lately principal and vicechancellor of the University of Edinburgh, has been elected by the General Committee president of the Association for next year, when the meeting will be held at York. Hitherto the president has assumed office at the inaugural meeting of the Association and has then given his presidential address. By an alteration of one of the Statutes, recommended by the Council and adopted by the General Com- mittee, the president will in future assume office on Jan. 1, will deliver his address at the annual meeting held during his year of office, and will retire at the end of the year. The advantages of these changes are stated by the Council as follows :

(1) The president will be responsible administratively for the major part of the preparation of arrangements for the annual meeting over which he is elected to preside, and his influence can be more directly brought to bear upon them.

(2) In particular, he will take the chair at the joint meeting of Organising Sectional Committees in the January preceding the annual meeting, which has now become a regular and principal part of the mechanism of preparing the programme.

(3) As a point of minor but still recognisable importance, he will arrive at the place of the annual meeting as president, not as president-elect, and possible confusion in the local public mind will be avoided.

(4) After the annual meeting he will still be in office to preside over those meetings of the Council at which matters arising out of the annual meeting are principally dealt with.

The new members of Council are Dr. J. Drever, Prof. T. E. Gregory, Prof. H. S. Hele-Shaw, Prof. E. B. Poulton, and Prof. A. M. Tyndall. Considerations of health would not permit Prof. F. J. M. Stratton to take full part in the preparations for the centenary meeting; and he cannot be present at next year's meeting. Prof. P. G. H. Boswell was therefore appointed as an additional general secretary. Prof. J. L. Myres, who has been one of the general secretaries of the Association since 1919, has intimated that he will not seek re-election after next year.

\section{Obituary.}

Prof. A. S. Pringle-Pattison.

$\mathrm{B}^{\mathrm{Y}}$ the death of Prof. Andrew Seth PringlePattison on Sept. 1, at the age of seventy. five years, philosophy lost one of the outstanding figures in a period of remarkable activity in that department. He was one of the first to see the significance for English thought of the impulse that came from the sympathetic study of Kant and Hegel in the 'sixties and 'seventies of last century. With the late Lord Haldane he organised the epoch-making manifesto contained in "Essays in Philosophical Criticism" which appeared in 1883 and included contributions from others who afterwards became famous in their several lines of research, J. S. Haldane, Bernard Bosanquet, W. R. Sorley, W. P. Ker, Sir Henry Jones, and James Bonar.

More cautious and more determined to make sure that no vital element in experience was being sacrificed to a first enthusiasm than some of his more ardent colleagues, Pringle-Pattison came forward in the next period of his philosophical development as a trenchant critic of what he held to be sinister features of the new movement. The doubts expressed in "Hegelian- ism and Personality" in 1887 seemed to be confirmed by the publication of Bradley's " Appearance and Reality " in 1893, and his essay in criticism of this work in "Man's Place in the Cosmos" seemed to separate him more widely still from his former idealistic associates. But the apparent recoil was only the preliminary to a more confident advance to the more personalistic form of that doctrine that found full expression in his Gifford Lectures in 1912-13 on "The Idea of God in the Light of Recent Philosophy" and has since had a growing influence both in England and America.

The general line of Pringle-Pattison's thought is indicated in the phrase which, so far as I know, he was the first to use of philosophy as " Criticism of Categories". The category prominent in nineteenth century thought was that of mechanical causation - the attempt to resolve everything into elements with which, as effect, it could be equated. This he held to be applicable (and possibly adequate) in certain limited spheres of phenomena, as in mechanics. But as we pass to other orders of fact, as to that of life, no preceding set of facts can account for their combination

No. 3231, VoL. 128] 